University of Louisville

ThinkIR: The University of Louisville's Institutional Repository

Electronic Theses and Dissertations

$12-1946$

\title{
A plastic protective film coating for metals.
}

Arthur S. Widzer 1914-2002

University of Louisville

Follow this and additional works at: https://ir.library.louisville.edu/etd

Part of the Chemical Engineering Commons

\section{Recommended Citation}

Widzer, Arthur S. 1914-2002, "A plastic protective film coating for metals." (1946). Electronic Theses and Dissertations. Paper 2200.

https://doi.org/10.18297/etd/2200

This Master's Thesis is brought to you for free and open access by ThinkIR: The University of Louisville's Institutional Repository. It has been accepted for inclusion in Electronic Theses and Dissertations by an authorized administrator of ThinkIR: The University of Louisville's Institutional Repository. This title appears here courtesy of the author, who has retained all other copyrights. For more information, please contact thinkir@louisville.edu. 
WIVERSTI of LOUISV IULE

A PLASTIC ProteCTIV FIM coATna

FOn Mratas

\author{
A Theats \\ Subitted to the paenlty \\ of the Craduate School \\ of the Datreraity of Louleville \\ In Partial Fulfilinant \\ of the Requilrenents \\ for the Degree of
}

MASTEA OF CHEATCAL EWGTHERIIV

Dopartant of Ohomical Englnoering

Arthur 5. Widser

Deoumber 1946 
A PLASTIC PROTECTIVE PIL COATING

FOR METALS

\section{Arthur S. WIdzer}

Approved by the Sxanining Comittee.

Daractor

R. C. Ernst

G. C. Williams

W. R. Barnes

Decomber, 2946 
The author wishos to acknowledge

the lind asalstance and helpful gutdance

of Dr. R. C. Brnet

who directed this researeh. 
comrewrs

Page

List of Tables............... v.

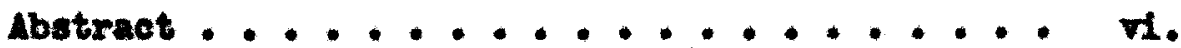
Introduction ................. 1 Hiotorieal ................ 3 Theoretical. ............... 5 Exporimontel ............... 12 Comorctal Foastbillty . . . . . . . . 22 Sumary and Conoluatons. ........... 24 Hterature cited .............. 26 $\Delta p \operatorname{spend1x} \ldots \ldots \ldots . \ldots . \ldots 28$ a. Womenelature ............ 29

b. Raw Matorials............ 80 c. Cost Caloulattons............. 31 d. Proliminary Data .......... 32 pita ..................... 88 
I refoet of Init1al Butyl Mathaczylate Polymer on MIIa Sardness ............................... 16

II Mrfect of Copelywarisation Time on Rardnose and sdhesion .........................

III Efrect of Styrene Concentration on Copolywer Properties ........................ 28

IV Effect of Curling Procedure on Konowar Loss ..... 19

V Investigation of Styrene and Nothylacrylate Copolyear ....................... 35

VI Inrest1gation of Wothylacrylate and Styrone Copolymor 34

VII Inveotigtion of Dutyl Hothorylate and styrone 
vi.

ABSTRACS 
A copolymer wa made to produce a protective Ilin of the destred properties. The two monomers ware (1) atyrom, becance of its 10 cost, high gloes, and chemical inertnese, and (2) butyl mothacrylate, because of 1 te good adheston to metal and its elose vapor preseure at $76^{\circ} \mathrm{C}$ to atyrene which ineured amooth surface free of bubbles.

Butyl nothacrylate and otyrene wore copolywarlsed; active centers of butyl methacrylate wore first formed, thon the styrene ma added. The polymerisation was not carried to completion, but to the deaired degree, which was determined by viscosity mensuresuente. The partially pelymertsed copolymer wae applied as a film on the matal surface to be protected. The rilu wa then completely polymerized 1ther by inframred hating for approximately five minutes, one hour in an oven at $110^{\circ} \mathrm{C}$, or one and ono-half hours in oumlight.

The copolyner f1lm produced in this way had a $4 \mathrm{H}$ hrinees, excelIont adheston and Plexibility, smooth surface, and high glose. It we chenicaily inert to hot and cold acids and eauetie. 
IMTRODUCTION 
A number of protective flin coatings contein drying olls. Tha gredual polymerisation of the drying oll in paint filme (due to the action of oxygen in the alr and sunlight) causes the peint flla to becom hard and brittle and to 1080 adheaton. This degradation reaulte In the eracking and peeling of the film leaving the netal surface umprotected.

I flin polymorised upon application would eliminate this diffioulty and produce a longer lasting protective flli. The chentonl inertneas Inharent in wany plastics would be an additional advantage. This could be accomplishod by the utilisation of an all plaste $11 . \mathrm{m}$.

A further advantage is that a Iong chain polywar could be formad thus helping adheaton. In laoquers, short chaln polywers are nocessarlly farmod so that the resin $w 111$ be more soluble (In it solvent). The short chain polyners decrease the dheston and posatble 11 in thioknoss per each Iaequer cont.

The problem becomes one of $\mathrm{flnding}$ the proper monomer or monomers to produce plastic wich would have the desired properties for a protective f1Im on motal, such as adhesion, hardness, floxibility, gloss and chomical Inertness, and weathering characterietles after polymoriation in place. 
HISTORICAL 
The development of synthatic polymere began with the polywerisation of styrene by B. SImon (9) In 1859. However, large seale development of synthetic polymers we not undertaken wall the close of the first world war.

In forming a polymer it is somotimes found advantegeoue to polymerise a mixture of two or nore nonomers to form a mixed polywer. Such polymers are known as copolywers. This process was discovered by katte (2914) (20) who observed the polymerization of a mixture of Vinyl esters. Later Voes and DLckbluser (1930) (11) observed the inoorporation of maleic acid Into polymerlining styrene. The nature of the process was recognised by WagnerJauregg (1980) (12) who described it as a hotero-polyweriation (copolymerisation). Durlig the past fen years copolymerization has been studied extenoively by many induetrial organisatione. The year 1942 was principally concerned with the rapid increase of synthette rubber prom duction by the copolywerlsation of butadiene and styrene to form Buna $S$. Vinyl polymers have boon studied particularly by C. S. Marvel and hia comorkers (13). 
THEORETTCAL 
The two monomers used for the copolyweriation in this study are styrene and butyl metheorylate. The reaction ia as follows:

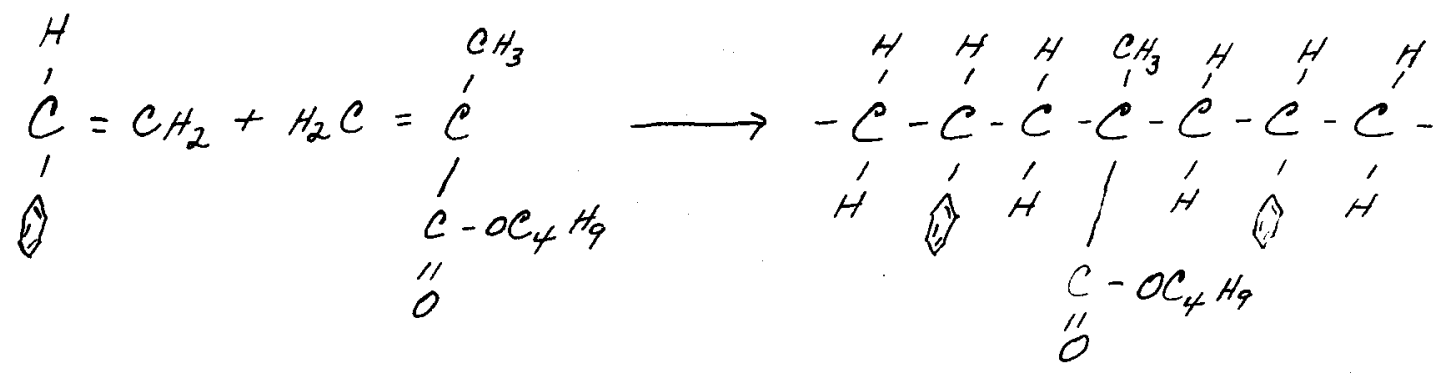

Styrone Butyl Wathecrylate $\longrightarrow$ Copolymar

The mechanian of afmple polymerisation of one monomer must be underotood before the theory of kinetios of copolymerlsation 1s undertaken. Polymerisation 18 a chain reaction and is thought to be inftiated by radicals. Many reaction proeed in chine, but in the polywerisation reaction the ohain realts in a large nolecule, which is the regult of the ability of the double bond to form now bonde while the original one remeine. This roaction is different fron condeneation polymerisation where a by-produet - often water, amonia, bydrogen chloride, or sodiun chlortde - is formed in addition to the polymor.

The reactions ocourring in polymerlsation are (I) ohain initiation, (2) chain growth, (5) chain trenufer, (4) branohing, and (5) chain onding. The reaction (1), (2) and (3) are thought to occur consecutively.

The formation of radicale which start the reaction is accouplishod by boat, Ilght, or catalyat but the type of radical formad by hoat or light has not been eatabliahod. In polymorisatione inftiated by poroxfdes, tho redieal is conaidered to be derived by decomposition of the peroxide, which cabines with the wonomer to form the radical as bensogl peroxide decomposes to give a phonyl radioal (15). 
$\left(\mathrm{C}_{6} \mathrm{H}_{5}(\mathrm{OO})_{2} \rightarrow \mathrm{C}_{6} \mathrm{H}_{5}{ }^{-}+\mathrm{H}_{2} \mathrm{C}=\mathrm{CHR} \rightarrow \mathrm{C}_{6} \mathrm{H}_{5} \mathrm{CH}_{2}-\mathrm{CH}^{-}\right.$

Bonzoyl Peroxide + Vinyl Monomor $\longrightarrow$ Radical

Bensoyl peroxide combines with the monomer to form a radical. The apparent onergy of activetion in the case of styrene is given as 25,000 26,000 cal. por mol. This apparent onergy of activation is dininished in the presence of eatelysts such as peroxides.

Polynerisation proceeds by the successive addition of monomer units to the radicals to form radicals of incroasingly larger alse. In this process molecules which do not polynerise by themselves may unite with the radical (activated moloculo). Copolymerisation results when a redical dioplays little cholce in the selection of a molecule with which to react. The hest of activation of this gronth-reaction is small; it 1s estimated at about 8000 cal. per nol., in the case of styrene.

According to Flory (14), it is possible for a radical to lose its onergy quantiun to anomerie molecule, thereby beconing deactivated, while the monomer now actu as a now radical. The course of polymerisation differs according to the various factors in oporation: the presence of many actire conters (radicals) may lead to the formation of short chains, fow actire contere, and no lapuritles to long chains.

Branching may oceur by the combination of a growing ehain and a polymor. The chain of the polymer comblnes to form a branch in the main chain.

The deactivation of the chaln occure as a result of varlous factors such as the combination of two groming ohains to form a single polymer by colliding wdth the wall of the vessel or wth molecule of another 
species. Certaln molecules are particularly offective in absorbing the energy of a growing ohain. These are called inhibitors.

The theory of kinetice of copolymertisation ha beon the oubject of a number of recent papers (1), (2). The authors of wich have recognized four cha In-propegating rate constante, governing the addition of monomer moleoules $X$ and $I$ to growing chain onding in $X$ and $Y$ units.

Wall (3), (4) has advanced a atmple theory and later an Improved theory bewed on free radical mochanism. Stmple theory of Wall.

If $I$ and $I$ represent concentration. of two mononers, each monomer disappeare in accordince of th the ftrat order - kinetics.

$$
\begin{aligned}
& d x / d t=-k X \\
& d x / d t=-k I
\end{aligned}
$$

From the quotient of equations (1) and (2) there was obtained

$$
\frac{d x}{d I}=\frac{k x}{k T}=\frac{2 x}{I}
$$

where $\alpha$ is the ratio of the opecific reaction ratio constants. Bquation (5) Is Identical with the difforentiel equation deceribing the bolling of a mixture of Iiquids which obey Reoulte' Ian. Fenee equation (8) any be considered the copolymerization counterpart of Raoulte' Lan of vapor prosaures.

\section{Inproved thoory of Wall.}

Asaunting a free radieal mochantom of chain growth, Norrish and Brookman (2) recognised that four different grouth resetions are possible during copolymerisation. These reactions are es follows: 


$$
\begin{aligned}
& \mathrm{Pax}+\mathrm{x} \stackrel{\mathrm{k}_{1}}{\longrightarrow} \mathrm{RxX} \\
& \mathrm{Ry}+\mathrm{x} \stackrel{\mathrm{k}_{2}}{\rightarrow} \mathrm{Ryx} \\
& \mathrm{Rx}+\mathrm{I} \stackrel{\mathrm{k}_{3}}{\longrightarrow} \mathrm{BxI} \\
& \mathrm{Ry}+I \stackrel{\mathrm{k}_{4}}{\rightarrow} \mathrm{Ry} I
\end{aligned}
$$

where $X$ and represent the two different monomers and $F x$ and $R y$ represent the two kinds of free radteals which can be characterised by the last added monomer unite. Assigning apeciflo resotion rete conatante $\mathrm{k}_{1}, \mathrm{k}_{2}, \mathrm{k}_{3}, \mathrm{k}_{4}$ to the reactions and letting the symbols also represent amounts of material (in moles) then the following rato equations can be writton:

$$
\begin{array}{ll}
d x / d t=-k_{1} R x x & -k_{2} h y x \\
d y / d t=-k_{g} R x I & -k_{4} R y I
\end{array}
$$

Wall explored the theorotical poestbilitiea ttondant upon many kindo of variation in the relative valus of the constants $k_{1}, k_{2}, k_{3}, k_{4}$ and has provided grephical representations of a nuber of cases, nowing the dependenoe of the rate of polymerisation and of polymer composition upon the cemposition of the alxture of monomers. Quoting WaII (4), "Copolynerization of etyrene and methyl wethacrylate by a free radical mechanten Indicates that the mononer reaction ratio 18 indopendent (within experimental errar) of the composition of the monomer mixture, the extent, and rate of conversion (proportione of bensoyl peroxide hasten the reaction)."

Jenkel (2) made an experimental study of the produets of polymar1sation of four monomer mixtures by fractionation and recognized that three of then repreaent true copolywera, while the fourth - the product of resction of styrene and rinyl acetate - more closely resemblea a mixture of ceparate polymers. Mayo and Lowle (6) devised a mothod for 
the evaluation of the retios $k_{1} / k_{2}$ and $k_{3} / k_{1}$ from the quantitative determinations of the composition of the copolymers ralative to that of the Inttlal monowar mixtures, and found that for the copolymorisation of styrene and mothyl nothacrylate at $60^{\circ} \mathrm{C}$ under a varlety of condfitions both these ratios were near 0.50 .

The chain mochanisa reaction is inftieted by a catalyst or othor source of energy ae light or heat. In general both hest and catalyst are ueed. The catalyats most comonly ueed are peraxides.

Robinson (16) has chom tint the decompostion of acetyl peroxides into free radicals follows generally the reaction

$$
\mathrm{R}-\mathrm{COO}-\mathrm{\infty OC}-\mathrm{R} \rightarrow \mathrm{R}-\mathrm{COO}+\mathrm{R}+\mathrm{CO}_{2}
$$

The free radical catalyzes the rection, and it was demonstrated that the peroxide restaues formed part of the chain. It has been shom that two-thirds of the moleculea after polymerisation contain $\overline{\bar{R}}$ radicals and one-third contalaed no50 radicals.

On the basts of the energy of activation of the decomposition rem action a nuber of peroxides have been classifled in the order of their effectiveness as cattlysts for atyrene. A partial I1st in the order of increasing activity is as followa:

\begin{tabular}{|c|c|c|}
\hline 1. Steary 1 & 5. Lauroy 1 & 9. Crotonyl \\
\hline 2. Ceproyl & 6. Capryl & 10. O-C1 bensoyl \\
\hline 3. An 1 soy 2 & 7. 0-toluyl & 11. GInnamoyl \\
\hline 4. 2 Butyryl & $\begin{array}{c}\text { 8. } 2-5 \text { dichlorom } \\
\text { benzoyl }\end{array}$ & $\begin{array}{l}\text { 12. d Proplonyl } \\
\text { 13. Napthoyl }\end{array}$ \\
\hline
\end{tabular}

Conversely in order to stop or slow down the polymerisation reaction rate, chemical inhibitors are used. The inhibiting action on otyrene has 
boen studied by Goldfingar, 3ke1st, and Mark (7). Thoy belleve that oach active center forand while there is still an apprectable coscentration of Inhibitor has no chance to grow out to a chaln but is deactivated by colIiston with a molecule of the inhibitor.

Thus the anount of inhibitor has an influence both on the length of the Induetion period and the final molecular wolght of the polymer formed.

Specifically, Foord (B) studied the effocts of wany groups as etyrene Inhibitors. Ho claseffiod then according to their Inhtbiting power (total prevention of polymerisation) and retarding power (decreased polymerieation rate and lower molecular wolght). He found the most effective groups to be

1. N1tro - good rotarder, woak inhtultor.

2. Phenolle hydraxide - fals retarder, woak Inhibitar. (Improve with the addition of hyciroxy groups)

3. Quinonold - woak retardor, strong inhibitor.

4. Witroso - wekk rotsrder, strong inhibitor.

5. Aalne - woak retarder, fair inhititor.

of necesalty oxygen is present while the film is being completely polymerised. The oxygen present during polymerisation is thought to incorporate in the pelymor chains form C-O-O-C- Iinkage. When heated the chain 1s broken preferentially at the $[-0-0]$ Inkage tecause of the lower bond onergy as compared to $-C-C-$. A catalytic froe radical of the $C=0$ forz may result which may ecelerate thermal decomposition. Oxygen present In ultra-violet polynerisation of styrene reduced the reaction rate and lowered the molecular melght of the product. This is not detrinental as the length of the molecule can be controlled, and a elen polymerisetion cyele is desired. 
EXPERTHENAT 
The exporimontal apparatus used in this invertigation consiated of a wahing unit, polymerisation reactor, and an auxiliary equipnent.

The weshing unit which consisted of a 500 c.0. aeparatory funnel and two 500 c.e. beakera was used for the removal of the hydroquinone inhtbitor from the monomers.

The polymerlation reactor conalated of a 125 c.c. erlenmeyer flask which was heated in water bath kept at $76^{\circ} \mathrm{C}$. Beosuse of the Iow vapor pressure and alow polymerization rate tho exlenaeyer was merely capped with a cork in which was inserted a glass tube. On the other and of the glaws tube a valved "Tm and an appirator bulb were attachod for the removing of aanples in order to deternine the riscosity of the solution so that the degree of polywortsetion could be followed. The Visoosty was measured by mean: of Oardiner Fiscosity Tubes.

An infra-red Ianp $(A=10,000$ and 20,000 units $)$ was ued as a source of hat for completely polymoriging the filn on the tal.

The metal panelo were steel plates s" $^{\prime}$ 5" $^{\prime \prime}, 18$ gauge and were propared for the $\mathrm{fII}$ by washing with a solvent to remove grease and oil.

The filn hardness was determined by the peneil hardness technique ("Ww through $\mathrm{gm}$ ).

The mononers as ahtpped contained a trace of inhibitor $(.0006 \%$ hydroquinone) whtch was removed before polywerization.

The Inhibitor was removed by a treatment of the nonomar with an equal volume of $2 \%$ sodiun hydroxide solution in a soparatory funnol. The solution of elkall, contelning the inhibitor, was drained from the botton of the funnel, and the washing was repeated until a freah portion of solution of alkali wa not discolored by contact with the monomer. 
Then the wonomer was washod twice with an equal rolume of distilled water. The all amount of water remaining in the monomer thon wes rewoved by alloming it to stand overnight in a refrigerator in contact with anhydrous sodium alfate or calciun chloride. Th desicoant was romoved by filtration.

Inhibitor free monomer was atored in a refrigerator at about $40^{\circ} \mathrm{p}$. Becaue the otyron molecule polymerised more radily than the butyl mathacrylate molecule, the butyl mothncrylate was placed in the reactor Wth the catalyot to form active centers for the copolymorisation. If this is not done a constderable amount of atyrone will polynerize with itaelf producing and insoluble perticles of polyretyrene which produces cloudy f1Im. The atyren was added and the two mononers pertially copolymerised to the desired degrea, we mosured by riscosity change.

The partially polymerised copolymer was then applied by dip, brush, or spray to a clean motal surface and furthor polymerized by heat, Infrered waves, or daylight.

The proeedure was as follows

Twenty-one grans of butyl methacrylate and 0.3 grame of bensoyl peroxide wore placed in the resctor and hold at $76^{\circ} \mathrm{C}$ intil the riseosity of the solution renched "B" in the Gardner V1soosity Tube (about four hours). Then nine graws of etyrene and 0.5 grane benxoyl peroxide wore added. The reaction was continued at $76^{\circ} \mathrm{C}$ unt11 the viecoalty becane "D" on the Gardner Viscosity Tube (about five additional hours). To the roalting partial copolymor an inhibitor was added (.006 grams of tertiary butyl catechol) which permitted atorage (away from aunlight) without continued polymerisation.

A ateel plate $\left(3^{n} \times 5^{n}\right)$ was then washed thoroughly with any good 
greave solvent or hot caustic. The partial copolywor was apread (as a filin) over the steel plate. The filin on the plate then was polymerized by one of trree methods:

1. Hre minutes under an inframred lamp.

2. Ono hour in an oven at $100^{\circ} \mathrm{C}$.

3. One and one-half hours in the sunlight.

The flin was tested by the uoual procedurea for adhesion, hraness, corrosion resiotance, and floxibillty (as described in "physical and Chemical Examination of Paints, Vamishes, Lequers and Colors" by A. A. (ardner).

Butyl wothecrylate and styrene were chosen to form the copolymer. Styrene was chosen because of its $10 \mathrm{w}$ coet, glose, hardmess, and low vapor preasure. In acrylate was chosen because of its goed adhealon to metals.

Thirty-nine teste in all (see appendix, prelininary data) were run before any good results were obtained. on the initial test runs styrone and wethylacrylate were copolymerized, producing a good adheatre film but poor aurface because of the formation of bubbles in the polymerised coating. The difference in the vapor presame of styrene mothylacrylate at $76^{\circ} \mathrm{G}$ caused the poor surface. Butyl mothecrylate was then chosen as 1 ts bolling point $\left(164^{\circ} \mathrm{C}\right)$ was close to otgrene's $\left(146^{\circ} \mathrm{C}\right)$, and it was aseumed that ito vapor pressure would be close to styrene's at $76^{\circ} \mathrm{C}$ and thereby obtain a amooth f1Im.

The copolymar was formulated to produce the desired illu hardneas, adhealon, flexibility, glose, and chentcel inertaoss. This was done by choosing the correct nonomers as explained abore, and by the control of the molecular welght and number of active centers of butyl mothacrylate and the total polymerisation cycle the. 
F1ln hardiness (4I pencll harchess) was obtalned by controliting the number and nolecular welght of active centers of butyl methacrylate. This was done by reacting the butyl mothacrylate first to the desired viscosity. This is Indicated by experinental results of tests $40,41,42$, and 48 . The Initial polymerisation tim of butyl mothacrylate in these test mes raried from two hours to five hours all other factora being hold conatant. The rooulting hardness rarled from pencll hardness to $5 \mathrm{~g}$ penell hardness.

Table No. 2

\begin{tabular}{|c|c|c|c|c|c|c|c|c|c|c|c|c|}
\hline \multirow[b]{3}{*}{ 10. } & \multicolumn{12}{|c|}{ WFBCT OF IAITIAL BUTYL METHACRTLATE POLMER ON FILY HARDNESS } \\
\hline & \multicolumn{2}{|c|}{ Composition } & \multicolumn{2}{|c|}{ Ist Poly } & \multirow{2}{*}{$\begin{array}{c}\text { Results } \\
\mu\end{array}$} & \multicolumn{2}{|c|}{ Composition } & \multicolumn{2}{|c|}{ and Poly } & \multicolumn{3}{|c|}{ Besults } \\
\hline & $\begin{array}{l}\text { acrylats } \\
\text { grs. }\end{array}$ & $\begin{array}{l}\mathrm{BaO}_{2} \\
\mathrm{grs}^{2} \text {. }\end{array}$ & $\theta$ & $t^{\circ} \mathrm{C}$ & & $\begin{array}{l}\text { Styrene } \\
\text { grs. }\end{array}$ & $\begin{array}{l}\mathrm{BsO}_{2} \\
\text { gra. }^{2}\end{array}$ & $\theta$ & $t^{\circ} \mathrm{C}$ & $\mu$ & H & Adh. \\
\hline 40 & 21 & .3 & 2 & 76 & 74 & 9 & .3 & 4 & 76 & A & H & E \\
\hline 42 & 21 & .8 & 3 & 76 & $7 \mathrm{~A}$ & 9 &. $\mathbf{s}$ & 4 & 76 & B & 3 五 & a \\
\hline 42 & 21 & .3 & 4 & 76 & $E$ & 9 & .3 & 4 & 76 & D & 4 If & $\mathbf{E}$ \\
\hline 45 & 21 & .8 & 5 & 76 & $\mathbf{D}$ & 9 & .3 & 4 & 76 & 0 & $5 \mathrm{H}$ & $\mathbf{E}$ \\
\hline
\end{tabular}

Whares

Bu Neacrylate............. Butyl Nothacrglate $\mathrm{BzO}_{2}$.................................. Peroxide

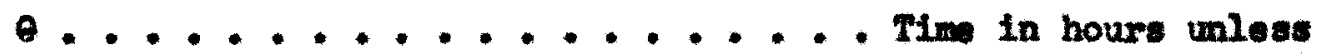
othervice epectified. $\mathrm{r}^{\circ} \mathrm{C} \ldots \ldots \ldots$ Temperature ${ }^{\circ} \mathrm{C}$

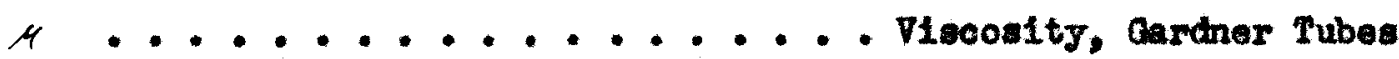
H ........................ Penell Hardneas 


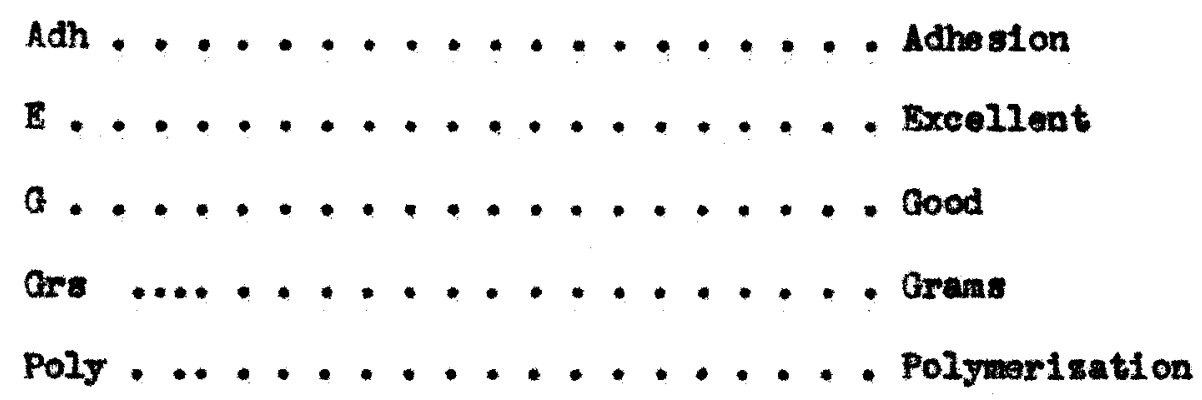

The polynerleed film showed excellent adhesion. This property was obtained by adjusting the temperature and oatalyst to give a long polymer1zation cycle, thereby groming long chatn wolecules which produce good adhealon. Short polymerisation cyoles produced ahort chain molecules. This 1s show by the experimental reaults of teete $44,45,46$, and 47 . The film becomes harder with Increased adhesion by the lengthenting of the totel polymerlsation time from six howrs to nine horrs, with but a apell Increase of vircosity.

Table No. II

\begin{tabular}{|c|c|c|c|c|c|c|c|c|c|c|c|c|}
\hline \multirow[b]{3}{*}{ No. } & \multicolumn{12}{|c|}{ WFET OF COPOLMERIZATION TIM ON HARDNESS AND ADHESTON } \\
\hline & \multicolumn{2}{|c|}{ Composition } & 1st & Poly & Results & \multicolumn{2}{|c|}{ Composition } & \multicolumn{2}{|c|}{ Rnd Poly } & \multicolumn{3}{|c|}{ Resulte } \\
\hline & $\begin{array}{l}\text { acrylate } \\
\text { grs. }\end{array}$ & $\begin{array}{l}\mathrm{AnO}_{2} \\
\mathrm{gra}\end{array}$ & $\bullet$ & $6^{\circ} \mathrm{C}$ & $M$ & $\begin{array}{l}\text { Styrene } \\
\text { grs. }\end{array}$ & $\begin{array}{l}\mathrm{BzO}_{2} \\
\mathrm{gra} .\end{array}$ & $\bullet$ & $t^{0} \mathrm{C}$ & $\mu$ & $\mathbf{H}$ & Adh. \\
\hline 44 & 21 & .8 & 4 & 76 & $\mathbf{B}$ & 9 & .5 & $\mathbf{2}$ & 76 & $A$ & $2 \mathrm{H}$ & a \\
\hline 45 & 21 & .3 & 4 & 76 & B & 9 & .5 & 23 & 76 & $\Delta$ & 28 & $a$ \\
\hline 46 & 21 & .8 & 4 & 76 & $B$ & 8 & .5 & 5 & 76 & $D$ & $4 H$ & $\mathbf{E}$ \\
\hline 47 & 21 & .3 & 4 & 76 & B & 9 & .8 & $5 \frac{1}{4}$ & 76 & $D$ & $4 \mathrm{~A}$ & $\mathbf{E}$ \\
\hline
\end{tabular}

For teat numbers $48,49,50$, and 51 epproximately the sam number and molecular welght of ective conter wore produced by controlling the Fiseoaity of the initial renctant (butyl bethacrylate). The total 
polymerization time was held conetant, and only the concentration of atyrone was rarled. The adhesion and hardness of the flnal product in each case was the same. The viscosity of the final solution was the only change noted. This verifles Wall's (4) staterant (see page 9). The excess styrene served as a solvent. Thus the viscosity of the final solution can be controlled, as noted in Table III. The styrene was varied from 5 grans to 17 grams, ell else kept constant. The only variation was the risoosty of the final solution.

Table No. III

\begin{tabular}{|c|c|c|c|c|c|c|c|c|c|c|c|c|}
\hline \multirow[b]{3}{*}{ Ho. } & \multicolumn{12}{|c|}{ 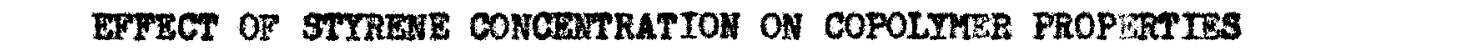 } \\
\hline & \multicolumn{2}{|c|}{ Composition } & \multicolumn{2}{|c|}{ lat Poly } & \multirow{2}{*}{$\begin{array}{l}\text { Reaulte } \\
M\end{array}$} & \multicolumn{2}{|c|}{ Composition } & \multirow{2}{*}{ 2nd } & \multirow{2}{*}{$\frac{\text { Poly }}{{ }^{\circ} \mathrm{C}}$} & \multicolumn{3}{|c|}{ Reoulte } \\
\hline & $\begin{array}{l}\text { acrylata } \\
\text { grs. }\end{array}$ & $\begin{array}{l}\mathrm{BzO}_{2} \\
\mathrm{gre}\end{array}$ & $\bullet$ & $t^{\circ} \mathrm{C}$ & & $\begin{array}{l}\text { Styreno } \\
\text { grs. }\end{array}$ & $\begin{array}{l}\mathrm{BaO}_{2} \\
\mathrm{grs}^{2}\end{array}$ & & & M & H & Adh. \\
\hline 48 & 21 & .3 & 4 & 76 & g & 3 & .3 & 5 & 76 & 0 & $4 \mathrm{H}$ & a \\
\hline 49 & 21 & .5 & 4 & 76 & $B$ & 6 & .3 & 5 & 76 & $\mathbf{E}$ & $3 \mathrm{H}$ & 0 \\
\hline 50 & 21 & .5 & 4 & 76 & $\mathbf{B}$ & 12 & 3 & 5 & 76 & $\Delta$ & $8 \mathrm{H}$ & 0 \\
\hline 51 & 21 & .3 & 4 & 76 & $\mathbf{B}$ & 17 & .3 & 5 & 76 & $>\mathbf{A}$ & $3 \mathrm{H}$ & $a$ \\
\hline
\end{tabular}

Good Plexibllity was obtained by the internal plasticisation of the copolymer (thus no additional plastlelser wa noceseary). Thls was obtalned by nolng the correot nonomers. In serylate copolymars good now characterIstica are obteined with a large compact molecule in the sido chaln so that the spatial compectness is in elose proxialty to the main chain" says Dr. Staudingor. This can be show by the formale of the polymorised chain. 


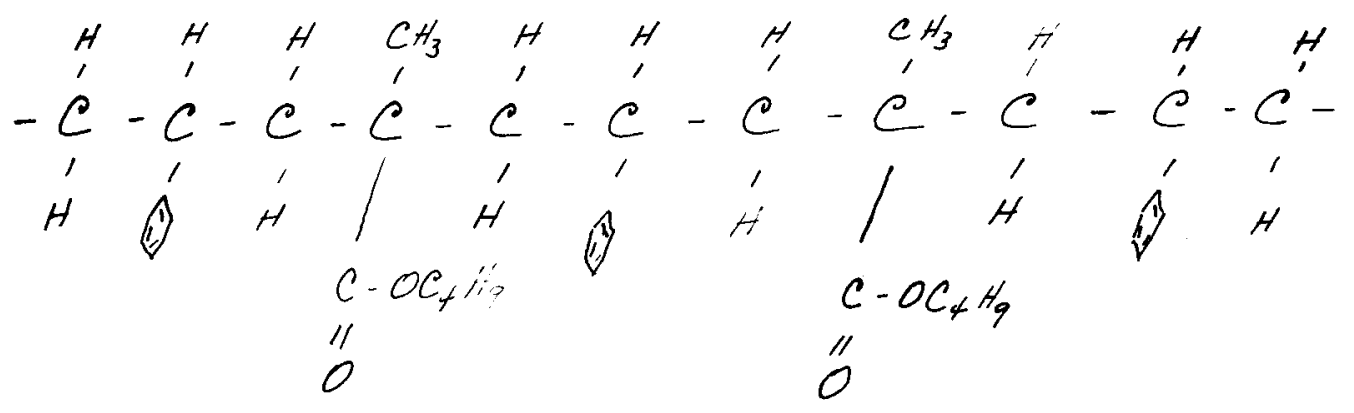

High gloss wes also obtalned by choosing the correct monowers which would produce a high glosa on polymerization.

The oure tim (complete polymerization) is atiafactory. It requires approximately five minutes for complete polywerisation under infra-rod waves, one hour in oren at $110^{\circ} \mathrm{C}$, one hour under ultra-violet rays, and on and one-half hours in sunlight. However, the monow loss (during the complete polymarization) is $\mathrm{high}(60 \mathrm{f})$. This percentage can be reduced by adding the catalyst to the copolymer before applying it to the motal aurface. However the smoothness of the film would be endangered by the formation of bubbles caused by the hat of resction by extremoly fast polymerisation. The flin at present is very smooth with good nowing character1st1ca. Experinental runs 52, 53, 54 and 55 show the cure time of the film.

Table Ho. IV

\begin{tabular}{|c|c|c|c|c|c|c|c|c|c|c|c|c|}
\hline \multirow[b]{3}{*}{ Ho. } & \multicolumn{12}{|c|}{ SEFBCT OF CURING PROCBDURE ON MONOMER LOSS } \\
\hline & \multicolumn{3}{|c|}{ Untra-V1olot } & \multicolumn{3}{|c|}{ Infra-Red } & \multicolumn{3}{|c|}{ Oren } & \multicolumn{3}{|c|}{ Sunlight } \\
\hline & $\$$ Lose & $\theta$ & $\mathbf{H}$ & \$ toes & 0 & t & 8 Lose & $\theta$ & $\mathbf{n}$ & Loes & $\theta$ & 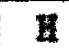 \\
\hline 52 & 98 & 1 br. & $2 \pi$ & 66 & 5 min. & 4 H & 70 & $1 \mathrm{hr}$. & $4 \mathrm{H}$ & 80 & & 2月 \\
\hline $5 \mathbf{5}$ & 55 & $1 \%$ & 28 & 65 & $5 *$ & $8 \mathrm{H}$ & 70 & 1 & 38 & 60 & $x^{2}$ & 48 \\
\hline 54 & 25 & 1 & $2 \mathrm{H}$ & 66 & $5 \%$ & $4 \mathrm{H}$ & 65 & 1 & 38 & 60 & 2. & $\mathbf{s R}$ \\
\hline $\begin{array}{l}\mathbf{5 5} \\
\text { Adhe }\end{array}$ & $\begin{array}{c}50 \\
100\end{array}$ & $\begin{array}{l}1 \\
\text { d on }\end{array}$ & 2H & $\begin{array}{l}\$ 5 \\
\text { mplos. }\end{array}$ & $5 \%$ & $4 \mathrm{II}$ & 60 & 1 & $2 n$ & 61 & $\begin{array}{l}2 \mathrm{z} \\
\text { hro. }\end{array}$ & 5 II \\
\hline
\end{tabular}


The torage ability of the partially copolyneriaed solution is very good. Two amples of solution - one Inhibited wth hydroquinone and one Inhibited with tertiary butyl catochol - were stored for three monthe and no apparent viscosity change he been notod.

Test runs were made on the plastio f1lm to determine the inortmess of the fllm. These test runs were made by soaking the $\mathrm{NIn}$ wth the teat solution for tmonty-four hours, and thoy showed thet the film was Impervious to alphuric acid (concentrated and diluted), hydrochlorio actd (coneentrated and diluted), caustio (50, both hot and cold, othnol, and wator, and w11l not diseolor undor witra-rolet radiation. The 11 in is soluble in most petroleam solvente.

The greatest difficulty during the experimentation was obtaining aufflclent bardness. Butyl Hotherylate 1tself is a soft polywar (about II pene11 hardneas). It tonds to make the copolyner soft and tacky. styrene on the other hand (which is a bard polymer) w11 react readily Wth itoelf causing cloudy film and very poor adheolon. Thus care had to be taken to control the degree of copolymerisation of butyl mothmorylate and syrene.

If the monowere of atyrene and butyl wathecrylate are alxed together and then polymerised, the resulte are not reproduclble, since thare is no control over the moleaular weight or number of aetive centere formed. The Inal solution 1s a mixtre of atyrene and copolymer.

4 redox (oxidation - reduction) type of catalyat was tried but falled. This type of catalyst had boen used to rodues the time of Vingl polynemsatione in water enulations from 18 hours to 15 minutes. This 
would be benefictel for reduction of the monower 108 during complate polymeriention providing the hat genarated during the fast polymerisati on reaction d1d not rutn the $\mathrm{rIIm}$ aurface by the formation of bubblea. 
CORERECIAL PEASIBILITI 
The all-plaetio filn is a comereially feasible produet. If dosirod 1t can be anufectured in jeoketed renotore of 1000 gallons or largor. The procese will lend itealf easily to a continnous polymerisation reaction

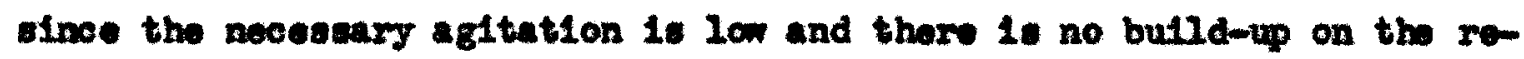
actor malla to interfore with the heat trancier. $A$ atean jacketed tube of deatred longth with two proportioning pumpa and two temperature controllere are all that are neceosary. The equipment may be bullt of atandard ateal plpe ance the vapor presaurea of both monomiss are low, and at the slom rate of polymerisation the vapar presure is not grout enough to pop a cork out of a toppered erlonnoyer Mak uned as a roactor durifg the polymariantion teate.

The raw interial cost for the mmuracture of one galion of eolution 13 $\$ 4.94$. The otean cont is negligible as the reaction 1 exothermic. "loat-up" stean plua a anll anount of make up, because of conduction and convection 10es, 1s moesanry. It takes one poimd of ateen at 150 p.s.1. to hoat four gallow of solution (beo cost enleviations in the appendix). 
SUMMARY AND CONCLUSIONS 
The polymeriantion of IIquid monomore to form an all plastle protective

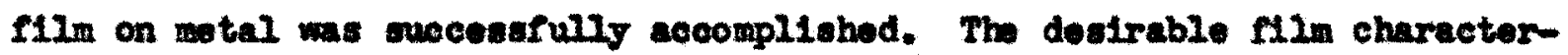
1atles (hardness, adheolon, flexibility, glose, and chemicel Inertnoss) wore obtained by the copolymerisation of atyrene and butyl athacrylate. The butyl methacrylate wa firat partially polywe rised to the deelred degree as Indicated by Iseostty nensuremente. The styrene wa added and the rolution was again partielly polymerised to the deatred degree. The partially polymorlzed copolymor was apread on the wotel panel which had boen washed wth a seivent to reacre any oll or grease. The panel was then polymerised 1ther by inframred honting for Nre minutes, ane hour in the oren at $110^{\circ} \mathrm{C}$, one hour under ultra-violet IIght, or on and onombulf houra in sunlight.

The rate of polymerisation was necessarliy slow for two reacone: (1) to control the dastred degree of polymarisation and (2) to form long chain noleculea. It he been proved by a number af obeervers that the longer the polywarisation ejole the longer the nolecular chain. This is desirable for adhoston purposed.

The additional plastielsera were of no benefit as the copolymer had good intornal plastiolastion characteriaties. The filn wae flexible to the degree of withstanding a blon by a hamer and a bend of 560 degrees. The elinination of drying o1l. (which ouue the detrinental polymertsation of aging paint) lengthene the Ilfe expectaney of the polymarised 11I. Thus, the all plaatie filn io a ouperior product to that of paint E11日e. 
LITERATURE CITED

$-$ 
1. Jenckel, Z. Ph. Chem. 190A, 24 (1941) (abetract).

2. Norrish and Brookmon, Pro, Roy. Soc. (London) 1171, 147 (1939) (abstract).

3. Wall, Ind. Eng. Chem. 63, 1862 (1941).

4. Wall, Ind. Bng. Chem. 66, 2050 (1944).

5. Alfrey and Doldfinger, J. Chea. Phys. 12, 205 (1944) (abatract).

6. Mayo and Lowis, J. of Am. Chom. Boc. 66, 1594 (1944).

7. Coldfinger, Skeist, and Mark, J. of Ph. Chem. 47, 578 (1940) (abstract).

8. S. Q. Foord, J. of Chem. Soc. (London) 48 (1940) (abstract).

9. E. Stmon Ann. 31, 267 (1839) (abstract).

10. F. Blotte, Austrien Pat. 70, 548 (1914) of the Crieshoin Eloctron Chem, Wks. (abstract).

12. Voss and Diekhlliser, D. R. P., 540, 101 (1980).

I. Q. Farbenindustriea A. - a. (abstract).

12. T. Warner - Jauregg, Bev, 63, 3213 (1938) (abstract).

23. C. S. Marvel - J. Am. Chem. Soc. 60, 280 (1938); 61, 324 (1939),

61,3156 (1989); 61, $3241(1939) ; 62,2666$ (1940); 64, 92 (1942).

14. P. J. Flory, J. Amer. Chom. Soc., 58, 1877 (1957).

15. H. Price, Ind. Bng. Chom., 34, 2343 (1942).

16. Robinson, J. of Chem. Soc. (Londion) 56 (1940) (abstract). 
APPENDIX 
MOMWCLATURE

Bu Moacrylate . . . . Butyl Mothmerylate

$\mathrm{BrO}_{2}$......... Bensoyl Peroxide

$t^{\circ} \mathrm{C}$........... Temperature ${ }^{\circ} \mathrm{C}$

๑........... Tim in hour mlese otherwi se opecifled

M........... Viscosity, Gardner mubes

H............. Pencll Hardnese

adh .................theation

\$........... Pereent monomer 100 of f1lm under infra-rod

while undergoing complete polymerizetion unless othorwlse opecified.

Heacrylate ...... Mothylacrylate

D.O.P. ....... DL Oetyl Pthulate

T.C.P. ......... Tr1 oreagl Phosphete

p.s.1. ......... Pounds per square Inch

H.Q. ......... Hydroquinone

T.B.C.. ........ Tert1ary Butyl Catechol

o ...............

L.......... Excellent

Poly. ......... Polymerisetion

Ors .......... Orams 
RAK MATERIAS

$\mathrm{CH}_{3}$
1

Butyl Mothacrglate..... $\mathrm{H}_{2} \mathrm{C}=\mathrm{C}-\mathrm{C}-\mathrm{O}-\mathrm{OC}_{4} \mathrm{H}_{9}$

Nolecular Weight. ..... 142.09

Specifle Gravity. ..... . 895

Bolling Point....... $163-164^{\circ} \mathrm{C}$

Cost ........... 754 par 2b. In 55 galion druss

(4000 2bs. or over)

Manufacturer. ...... Bohr and Hase, Philadelphta, Pa. Styrene .................... $\mathrm{C}_{6} \mathrm{H}_{5} \mathrm{CH}^{\mathrm{CH}_{2}}$

Nolecular Velght. ..... 104.14

Specifle Gravty....... ..905

Bolling Point....... $145-146^{\circ} \mathrm{C}$

cost ......... 14 ... per 1b. In 55 galion druas (carload 1ota)

Manufacturer. . ..... Don Chemical Co., Midland, Mich. Bensoyl Peroxide........ $\left(\mathrm{C}_{6} \mathrm{H}_{5} \mathrm{CO}\right)_{2} \mathrm{O}_{2}$

Holecular Weight. ..... 242.22

Welting Point...... $108^{\circ} \mathrm{C}$

cost ......... \$4.50 per $2 \mathrm{~b}$.

Hinufacturer. ....... Lucldol Co., Buffalo, N. Y.

P-Tertlary Butyl Catechol.... $\mathrm{C}_{3} \mathrm{H}_{5}(\mathrm{OH})_{2} \mathrm{C}_{4} \mathrm{H}_{9}$

cost .........\$1.40 per 1b.

Manufacturex. ...... Dow Choalcal Co., Midland, Mich. 
specific hat of styrene ............... 32 B. T.U. per Ib. Spectf1c hat of butyl motherylate. ......... .45 B.T.U. per Ib. Spectele gravity of oopolywer. . . . . . . . . . 9

Weight of copolyuer .............. 7.5 Ibs, per gallon gaw meterial coat

21 Ibe. butyl wothyl mathecrylate $\$ 0.75$ per $2 \mathrm{~b} . \$ 15.75$

9 1bs. atyrene $0.14 \frac{2}{4}$ per 16......... 1.28 $.6 \mathrm{2b} . \mathrm{BsO}_{2} 84.50 \mathrm{per} \mathrm{2b}$. . . . . . . . 2.70 .006 2b. T.B.C. \$1.42 per Ib. ...... 0.01 Total ...................... \$19.75

so 1bs. copolymer / 7.5 .............4 gellons

1 gallon costa $\$ 19.75 / 4 \ldots . \ldots 4$

Steam cost

$$
Q=\left(2 b_{.}\right) \text {(Temp. Diff.) (Sp. Ht.) }
$$

For otyrone

(9) $(169-75)(.32)=271$ B.T.U.

For butyl wothacrylate

(21) $(169-75)(.45)=890$ B.T.0.

Total ....... 1161 B.T.U. (to hoat batoh fron $75 \%$ to 169\%)

1 1b. atean at 250 p.s.1. $=1198.4$ B.T.U.

Thus it requires 1 pound of stean at $150 \mathrm{p.s.1}$. to heat 4 gellons of copolymer to resction temperature. If stean costs 54 per pound it would cost $1 \frac{1}{4}$ per pound to beat one gallon to reaction temperature. 

Table Ho. V

Prolininary Data

\begin{tabular}{|c|c|c|c|c|c|c|}
\hline \multicolumn{7}{|c|}{ INVESTIOATTON OF STYREME AND METHYLACRYLATE COPOLYMER } \\
\hline & \multicolumn{4}{|c|}{ Composition } & \multirow{2}{*}{$\begin{array}{l}\text { Infra- } \\
\text { Red } \\
\text { Waves } \\
0 \text { ain. }\end{array}$} & \multirow[b]{2}{*}{ Remarka } \\
\hline No. & $\begin{array}{l}\text { styrene } \\
\text { grs. }\end{array}$ & $\begin{array}{l}\text { Me- } \\
\text { acrylate } \\
\text { grs. }\end{array}$ & $\begin{array}{l}\mathrm{BmO} 2 \\
\mathrm{gra}\end{array}$ & $\begin{array}{c}\text { T.O.P. } \\
\text { gro. }\end{array}$ & & \\
\hline 2 & 10 & & .2 & & 10 & $\begin{array}{l}\text { Filn too bxittie, no } \\
\text { adhesion. }\end{array}$ \\
\hline 2 & & 10 & .2 & & 10 & soft mas. \\
\hline $\mathbf{s}$ & 8.5 & 2.5 & .02 & & & Solution Imiatble. \\
\hline 4 & 2.8 & 8.5 & .02 & & 10 & $\begin{array}{l}\text { Solution eloudy, poor } \\
\text { surface (bubbles), } \\
\text { brittle fllm. }\end{array}$ \\
\hline 6 & $\begin{array}{l}1.7 \\
1.7\end{array}$ & $\begin{array}{r}8.6 \\
8.5\end{array}$ & $\begin{array}{l}.02 \\
.03\end{array}$ & 8.4 & 10 & $\begin{array}{l}\text { On addition of } 5.4 \text { gra. } \\
\text { D.0.P. solution becama } \\
\text { cloudy. }\end{array}$ \\
\hline 7 & 1.5 & 8.5 & .08 & .05 & 10 & Too much plastielser. \\
\hline 8 & 5 & 17.9 & .08 & .2 & 10 & .2 to 5 gran T.C.P. \\
\hline 9 & $\mathbf{3}$ & 17.0 & .08 & .5 & 10 & plasticizer. Poor \\
\hline 10 & $\mathbf{3}$ & 17.0 & .08 & .3 & 20 & I pendl i hardneas. \\
\hline
\end{tabular}


Table No. VI

Preliminary Data

\begin{tabular}{|c|c|c|c|c|c|c|c|}
\hline \multicolumn{8}{|c|}{ INVESTICATION OF METHYLACRYLATE AND STYRENE COPOLMER } \\
\hline \multirow[b]{2}{*}{ No. } & \multicolumn{4}{|c|}{ Composition } & \multicolumn{2}{|c|}{ Poly } & \multirow[b]{2}{*}{ Remarka } \\
\hline & $\begin{array}{c}\text { Styrene } \\
\text { gra. }\end{array}$ & $\begin{array}{l}\text { He- } \\
\text { serylate } \\
\text { grs. }\end{array}$ & $\begin{array}{l}\mathrm{BzO} \\
\mathbf{8 x}\end{array}$ & $\begin{array}{c}\text { T.C.P. } \\
\text { gre. }\end{array}$ & $t^{\circ} \mathrm{C}$ & $\theta$ & \\
\hline 11 & 6 & 38.6 & .1 & .4 & 76 & 1 & Poor flin (bubbles). \\
\hline 12 & 6 & 86 & .1 & .4 & 76 & 2 & Poor filn (bubbles). \\
\hline 18 & 6 & 36 & .1 & .4 & 76 & 5 & Becem volld over night. \\
\hline 14 & 6 & 36 & .1 & .4 & 76 & 5 & Became solid over night. \\
\hline 15 & 6 & 36 & 0 & .8 & 76 & 12 & No polymerlsation. \\
\hline 16 & 6 & 36 & 0 & .3 & 76 & 12 & No polymerization. \\
\hline 17 & 6 & 36.5 & .1 & .2 & 76 & 3 & $.01 \mathrm{H.Q}$. Inhibitor added. \\
\hline 18 & 6 & 37.6 & .1 & .5 & 76 & 3 & .01 H.Q. Inhibitor added. \\
\hline
\end{tabular}

Romarke:

It is evident that the difference in bolling point of mothacrylate $\left(80^{\circ} \mathrm{C}\right)$ and styrene $\left(146^{\circ} \mathrm{C}\right)$ caued the bubbles in the surface during total polymerization. Therefore butyl wethacrylate bolling point $\left(164^{\circ} \mathrm{C}\right.$ ) was ordered. Tests No. 17 and 18 were tests on inhibitors for determining if the solution can be stored. The riscosity of the two samples remained the sane over a three month period. 
Table No, VII

Proliminary Date

\begin{tabular}{|c|c|c|c|c|c|c|c|c|c|c|c|}
\hline \multirow[b]{3}{*}{ No: } & \multicolumn{3}{|c|}{ IWVESTIGATION OI } & \multicolumn{2}{|c|}{ BUXYL $\mathrm{M}$} & \multicolumn{2}{|c|}{ WTACRILATE AND } & \multicolumn{3}{|c|}{ TREDS COPOLMMER } & \multirow[b]{2}{*}{ Results } \\
\hline & Comp & oosit. & on & lat & Poly & Rasulta & Composit & Ion & Rnd & Poly & \\
\hline & Moncmer & $\begin{array}{l}\mathrm{BxO} \mathrm{O}_{2} \\
\mathrm{gre}^{2}\end{array}$ & T.C.P & $\theta$ & $t^{\circ} \mathrm{C}$ & $\mu$ & Monomer & $\begin{array}{l}\mathrm{BaO}_{2} \\
\mathrm{gra}^{2}\end{array}$ & $\theta$ & $t^{\circ} \mathrm{C}$ & $\mu$ \\
\hline 19 & $\begin{array}{l}10 \mathrm{gra} \\
\text { Bu Ho- } \\
\text { acrylate }\end{array}$ & & & & & & & .3 & 8 & 76 & \\
\hline 20 & $\begin{array}{l}5 \text { gre. } \\
\text { tyrene }\end{array}$ & & .5 & & & & $\begin{array}{l}21 \text { gre. } \\
\text { Bu Ho- } \\
\text { corylete }\end{array}$ & .6 & 8 & 76 & $\mathbf{A}$ \\
\hline 21 & $\begin{array}{l}8 \mathrm{gre} \\
\text { atfreme }\end{array}$ & & .5 & & & & $\begin{array}{l}21 \text { gro. } \\
\text { Bu Ko- } \\
\text { eerylate }\end{array}$ & .6 & 2 & 76 & $\mathbf{A}$ \\
\hline 22 & $\begin{array}{l}3 \mathrm{gxa} \\
\text { styrene }\end{array}$ & .3 & .6 & 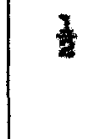 & 76 & $\mathbf{A}$ & $\begin{array}{l}21 \text { grs. } \\
\text { Bu Fo- } \\
\text { acrylate }\end{array}$ & .5 & 5 & 76 & $\mathbf{A}$ \\
\hline 23 & $\begin{array}{l}3 \text { gxa. } \\
\text { styrene }\end{array}$ & .3 & .6 & $\frac{1}{2}$ & 76 & $\mathbf{A}$ & $\begin{array}{l}21 \text { grs. } \\
\text { Bu fo- } \\
\text { ecrylate }\end{array}$ & .3 & 5 & 76 & 4 \\
\hline 24 & $\begin{array}{l}21 \text { gra. } \\
\text { Bu Ho- } \\
\text { acrylate }\end{array}$ & .3 & .6 & $\frac{1}{2}$ & 76 & $\boldsymbol{\Lambda}$ & $\begin{array}{l}6 \mathrm{gres} . \\
\text { otyrene }\end{array}$ & .8 & 5 & 76 & $\mathbf{D}$ \\
\hline 25 & $\begin{array}{l}21 \text { grs. } \\
\text { Bu He- } \\
\text { acrylate }\end{array}$ & .8 & .6 & $\frac{1}{2}$ & 76 & $\boldsymbol{A}$ & $\begin{array}{l}5 \text { ses. } \\
\text { etyrene }\end{array}$ & .8 & 5 & 76 & $\mathrm{c}$ \\
\hline 26 & $\begin{array}{l}21 \text { gro. } \\
\text { Bu He- } \\
\text { acrylate }\end{array}$ & .3 & & 4 & 76 & Syrup & $\begin{array}{l}9 \text { gra. } \\
\text { atyrono }\end{array}$ & .5 & 4 & 76 & $c$ \\
\hline 27 & $\begin{array}{l}21 \mathrm{gra} \\
\text { Bu He- } \\
\text { ecrylate }\end{array}$ & .3 & & 4 & 76 & Syxup & $\begin{array}{l}\text { gres. } \\
\text { tyrome }\end{array}$ & .5 & 4 & 76 & $c$ \\
\hline
\end{tabular}




\section{Romarks:}

Test No.

19. This was the butyl motheorylate monomer polymorlsed by itself. The polywer was softer than 18 poncll hardness and had good adherion.

20. Styrene and batyl nethacrylate wero combinod and polynerised. and The $211 \mathrm{n}$ had a hardnese of $2 \mathrm{H}$, showed fair adhesion and an $80 \%$ 21. woner 1009 on complete polymerization under Infra-red lamp for fire minutes.

22. Styrone wa firot added and polymerised initially for one-half and hour at $76^{\circ} \mathrm{C}$, then the butyl wetherylate we added in smel 25. droplets for a period of five hours. The colution was cloudy and the resultant $\mathrm{fII}_{\mathrm{m}}$ ooft and taoky.

24. Th butyl, nothacrglate was firat added and polymerised initially and for on-half how at $76^{\circ} \mathrm{C}$, then the styreno was added in amall 25. droplete for a pertod of five hours. The IIIn had 1 penc1l hardness and good adholon and showed a 60, monomer $10 a s$ on complete polymerisation of the film on the panel.

26. By polywerleleg the batyl wathecrylate to ayrup conotituoncy and the 217 becave herder. 111 the atgrene was added at on thas 27. no plastleiser we used. The flin was flexible enough from internel plastleisation of the copolymer. The FIm would not chip on receiving a arp blew wib a haver. The hardness of the fllm was 5I pene1I hardnoss; the adbesion was excellent and shored a $50 \%$ monomer $10 \%$ on complete polymerlation. 
Vaing No. 26 copolymer, taete were run to determine whether certein plactlefsere were of any ralu. The reaulte wore as follows

\begin{tabular}{|c|c|c|}
\hline Test No. & Plastlolser & $P 11 n$ \\
\hline 28 & Aroclor 1254 & Tacks \\
\hline 29 & Aroclor 2260 & Taciky \\
\hline 30 & Aroclor 4465 & Brittie \\
\hline $\mathbf{s 1}$ & Pareplex RO-B & No adheston \\
\hline 82 & Paraplex $\mathrm{RO} 2$ & Ho adherion \\
\hline $\mathbf{3 5}$ & Resyl $x-315$ & No adhostion \\
\hline
\end{tabular}

Rodox eatalyat (oxidising reducing catalyot) is stronger than Bonsoyl Peroxide alone as a catalyst; thu Bensoyl Peroxide plus several reducing agents were used to txy to find a stronger eatelyat to reduce the monomer loss on complete polymerisation.

Ualng Vo. 27 copolymer and .5 gra. of Bensoyl Peraxide and .2 gre. of reducling agent, the results were the following:

\begin{tabular}{|c|c|c|}
\hline Teet No. & Reducing Agent & Reawl to \\
\hline 84 & Butyl Mdehyde & No polymorization \\
\hline $\mathbf{5 5}$ & Furfural & Cauwed a procipitate \\
\hline 36 & $\begin{array}{l}\text { Bensidine } \\
\text { Hydrochlortde }\end{array}$ & Insoluble \\
\hline$\$ 7$ & Sodiun sulphide & Ineoluble \\
\hline 88 & $\begin{array}{l}\text { Hydrexylomine } \\
\text { Evdrochloride }\end{array}$ & 511ght1y colubla \\
\hline$\$ 9$ & Densin Aldohyde & Poor - tacky f1In \\
\hline
\end{tabular}


VITA 


\section{ARTHUR SHELDON WIDEER}

The Author is the son of Lewis Jack Widser and Sarah Saltuper WIdeer. Eie wee born in Myria, Ohto, on the elxth of Dobrury, 1914 .

He attended lewentary behool at Bromell located in Byrin, Ohio, and high sohool at net Teobnioal in Clevelend, Ohto.

The Author sttended four Collegen. At Case School of Applied Solence he recelved his Bechelor of solence degree in Chomien Ingineering. His under graduate thesis concerned the acration of varnishes and was directed by Dr. C. F. Prutton, houd of the Chemion IngIneering Dopartment. Be thon attended Cloveind Colloge at alghts undortaking a Buef naea Idainistration course supervised by W. D. White. He eatered the Craduate School of Cincl mnet1 Dniveratty atudying uader Dr. C. Oreon. He then entered the Oradute School of the Univeraity of Loulaville, where Dr. R. C. Brast wa his councalor.

We ha bad Industrinl experionce of th J. B. Seagran and Sons, Ino., of Loulev111e, Kontuekg! The sartion Rolling Mlle of Middlotow, Ohios The Aneco Chemical Company of Rocheater, How York; the Basterly Somge Dioposal Plant of Cloveland, Ohios and B. F. Ooodrich Chouteal Company. aeon Plant, of Loulevillo, Kentudry. 